\title{
ROZLIŠENÍ VZDÁLENÝCH ZÁZNAMŮ PŘIROZENÝCH ZEMĚTŘESENÍ A EXPLOZÍ NA PŘÍKLADU SEVEROKOREJSKÝCH JADERNÝCH TESTŮ
}

\author{
Teleseismic records discrimination of natural earthquakes and explosions on the example \\ of the North Korean nuclear tests
}

\author{
Josef Havír \\ Ústav fyziky Země, PřF MU, Tvrdého 12, 60200 Brno; e-mail: havir@ipe.muni.cz
}

Key words: seismic monitoring, CTBTO, nuclear explosions, discrimination methods

\begin{abstract}
North Korea is the only country conducting nuclear explosions after year 2000. In the period 2006-2016, there five nuclear explosions conducted at the nuclear test site Punggye-ri in the NE part of the North Korea. Body wave magnitude mb of last event reaches value 5.3 according to U.S. National Earthquake Information Centre NEIC and NDC Brno. It shows, that the last event is strongest explosion up to now. Many seismic stations registered signal related to North Korean nuclear tests, including broadband seismic stations operated by IPE (Institute of Physics of the Earth). One of these stations, station VRAC, is part of the International Monitoring System CTBTO focused on the verification of the compliance with the Comprehensive Nuclear-Test-Ban Treaty. Detection and location of events is not sufficient for such verification, the discrimination between records of natural earthquakes and explosions is necessary as well. Considering huge amount of data (more than 37.000 events located in the International Data Centre CTBTO during year 2016), the routinely used discrimination methods have to be simple and self-acting. First discrimination can be simply based on location and hypocentre depth evaluation. Other broadly used method is focused on comparison of Ms:mb magnitudes. Third method discussed in this article is method of quantification of complexity (ratio of coda to signal energy). The North Korean nuclear tests show higher Ms values (regarding to $\mathrm{mb}$ ) than is expected for nuclear explosions. On the contrary, the preliminary computed values of complexity are typically low for the North Korean nuclear tests, but their calculation strongly depends on the signal to noise ratio. Thus, combination of both methods (Ms:mb magnitudes and complexity evaluation) seems to be more appropriate for discrimination of events like the North Korean explosions rather than individually applied criterions.
\end{abstract}

V průběhu roku 2016 byly na jaderné střelnici Punggye-ri v sv. části KLDR uskutečněny hned dvě pokusné jaderné exploze. Problematika jaderných testů patř́i k nejvýznamnějším politickým otázkám sledovaným od druhé poloviny 20. století až do současnosti. Dlouhodobé snahy směřující $\mathrm{k}$ úplnému zákazu jaderných testů vyústily $\mathrm{v}$ roce $1996 \mathrm{k}$ předložení Smlouvy CTBT (Comprehensive Nucelar-Test-Ban Treaty) Valnému shromáždění OSN. Tato Smlouva byla do konce loňského roku podepsána celkem 183 zeměmi světa a ratifikována $166 \mathrm{z}$ nich (Česká republika ratifikovala Smlouvu CTBT již v roce 1997). Oficiální platnost Smlouvy je podmíněna podpisem a ratifikací 44 vybranými státy disponujícími jadernými zařízeními, mezi nimiž figuruje také KLDR. Smlouva CTBT tedy dosud oficiálně nevstoupila v platnost. Většina zemí v současné době přesto respektuje politickou nepřijatelnost provádění pokusných jaderných explozí. Severní Korea je jedinou zemí, která po roce 2000 uskutečnila jaderné exploze.

\section{Severokorejské jaderné testy a jejich registrace}

KLDR uskutečnila na své jaderné střelnici Punggye-ri v sv. části země (obr. 1) v letech 2006 až 2016 celkem pět pokusných jaderných explozí (tab. 1). Magnitudo mb počítané z objemových vln dosáhlo $\mathrm{v}$ př́ípadě posledního testu, ze dne 9. 9. 2016, hodnoty 5,1 (podle IDC CTBTO) až 5,3 (podle NEIC a NDC Brno). Zatím poslední jaderná exploze uskutečněná na území KLDR byla tedy nejsilnější $\mathrm{z}$ diskutovaných pěti událostí.
Seismický signál odpovídající severokorejským jaderným testům byl registrován množstvím seismických stanic, včetně stanic provozovaných Ústavem fyziky Země

Tab. 1: Tabulka lokací všech pěti jaderných testů provedených v sv. části KLDR v letech 2006-2016; lokace vypočítané nezávisle v NDC v Brně (NDC Brno), v Mezinárodním datovém centru CTBTO (IDC) a v centru americké národní seismologické služby (NEIC). Magnitudo mb je počítané z objemových vln. Tab. 1: Location parameters of all five nuclear explosions conducted in NE part of the North Korea during period 2006-2016; locations were independently determined at the National Data Centre in Brno (NDC Brno), at the International Data Centre CTBTO (IDC) and at the U.S. National Earthquake Information Centre (NEIC). Magnitude $\mathrm{mb}$ is calculated using body waves.

\begin{tabular}{|c|c|c|c|c|l|}
\hline \multicolumn{1}{|c|}{ datum } & čas vzniku & zem. šírka & zem. délka & mb & \multicolumn{1}{|c|}{ zdroj } \\
\hline 9.10 .2006 & $01: 35: 25.7$ & 41,269 & 129,472 & 4,1 & NDC Brno \\
\hline 9.10 .2006 & $01: 35: 27.6$ & 41,312 & 129,019 & 4,1 & IDC \\
\hline 9.10 .2006 & $01: 35: 27.9$ & 41,311 & 129,114 & 4,2 & NEIC \\
\hline 25.5 .2009 & $00: 54: 42.5$ & 41,237 & 129,052 & 4,8 & NDC Brno \\
\hline 25.5 .2009 & $00: 54: 42.8$ & 41,311 & 129,046 & 4,5 & IDC \\
\hline 25.5 .2009 & $00: 54: 43.1$ & 41,299 & 129,030 & 4,7 & NEIC \\
\hline 12.2 .2013 & $02: 57: 50.9$ & 41,287 & 129,118 & 5,1 & NDC Brno \\
\hline 12.2 .2013 & $02: 57: 50.8$ & 41,301 & 129,065 & 4,9 & IDC \\
\hline 12.2 .2013 & $02: 57: 51.3$ & 41,308 & 129,076 & 5,1 & NEIC \\
\hline 6.1 .2016 & $01: 30: 00.6$ & 41,296 & 129,065 & 5,0 & NDC Brno \\
\hline 6.1 .2016 & $01: 30: 00.5$ & 41,304 & 129,048 & 4,8 & IDC \\
\hline 6.1 .2016 & $01: 30: 01.5$ & 41,300 & 129,047 & 5,1 & NEIC \\
\hline 9.9 .2016 & $00: 30: 01.2$ & 41,287 & 129,055 & 5,3 & NDC Brno \\
\hline 9.9 .2016 & $00: 30: 00.9$ & 41,299 & 129,049 & 5,1 & IDC \\
\hline 9.9 .2016 & $00: 30: 01.9$ & 41,298 & 129,015 & 5,3 & NEIC \\
\hline
\end{tabular}



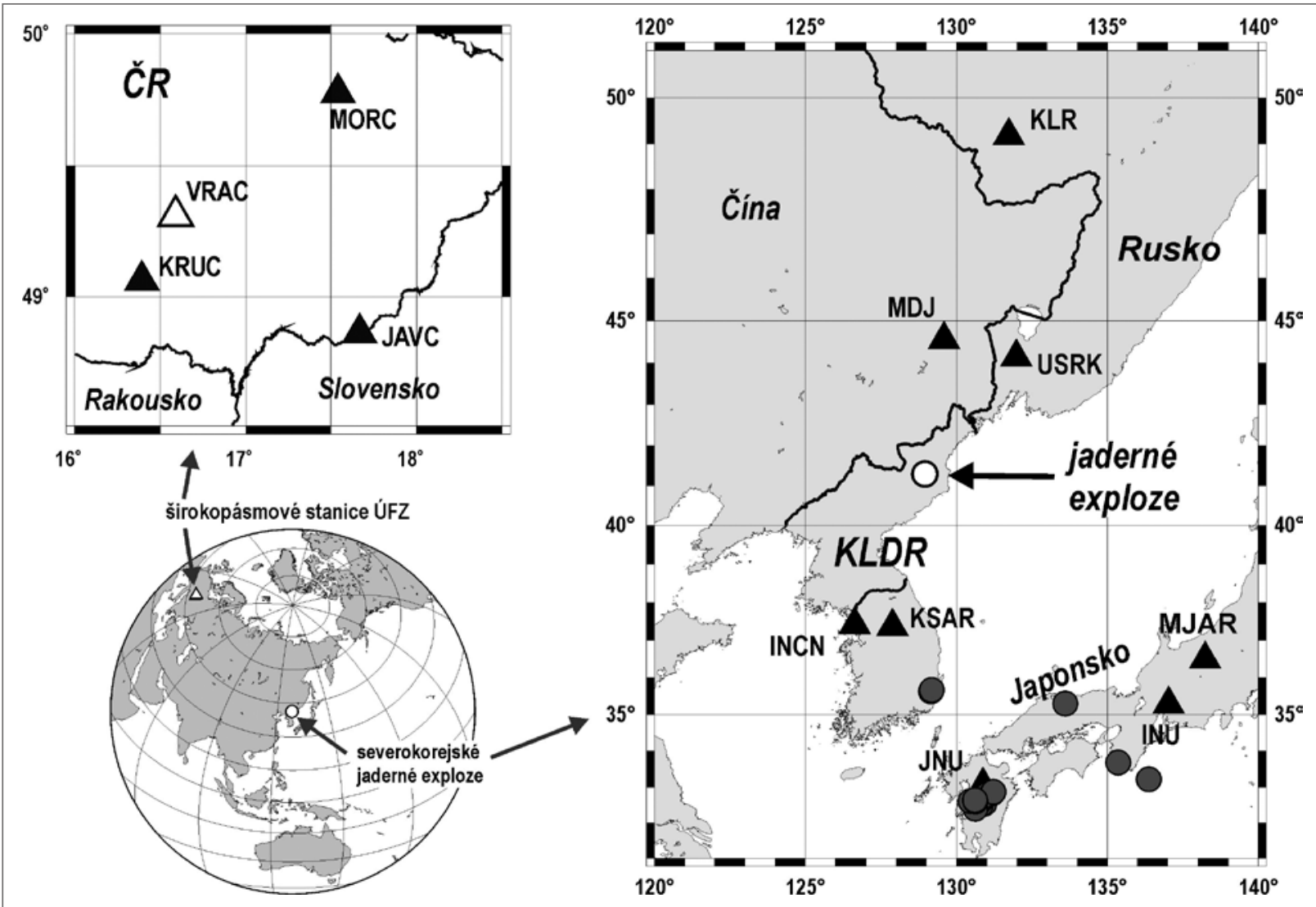

Obr. 1: Schematické mapy umístění širokopásmových stanic provozovaných ÚFZ (vlevo nahoře i dole) a epicenter severokorejských jaderných explozí z let 2006 až 2016 v globálním měřítku (vlevo dole) a v detailním výřezu (vpravo): trojúhelníky - pozice stanic využitých v ÚFZ k lokaci explozí (bílý trojúhelník - stanice VRAC; černé trojúhelníky - ostatní stanice); bílá kolečka epicentra jaderných explozí; šedá kolečka - epicentra přirozených zemětřesní využitých pro studium komplexity severokorejských jaderných explozí (blíže viz text).

Fig. 1: Schematic maps of position of the broadband seismic stations operated by IPE (left maps) and epicentres of the North Korean nuclear explosions from period 2006-2016 in the global scale (lower left map) and in the regional scale (right map): triangles - stations used by IPE for location of nuclear explosions (white triangle - station VRAC; black triangles - other stations); white circles - epicentres of the nuclear explosions; grey circles - epicentres of natural earthquakes used in the frame of complexity study of the North Korean nuclear explosions (see text for other information).

(ÚFZ) Masarykovy University v Brně (ÚFZ provozuje, mimo jiné, čtyři tzv. širokopásmové stanice, viz obr. 1). Mezi stanicemi ÚFZ hraje zvláštní roli stanice VRAC, která je součástí Mezinárodního monitorovacího systému CTBTO budovaného za účelem verifikace dodržování Smlouvy CTBT (Hoffmann et al. 1999). Do konce roku 2016 bylo v rámci tohoto systému vybudováno a certifikováno celkem 149 seismických stanic rozmístěných po celém světě. Kromě seismického monitorování využívá Mezinárodní monitorovací systém CTBTO také další technologie a to infrazvukovou, hydroakustickou a radionuklidovou. Data všech monitorovacích zařízení jsou shromažd’ována a zpracovávána v Mezinárodním datovém centru (IDC) umístěném ve Vídni.

Provoz jednotlivých zařízení sítě CTBTO zajištují tzv. Národní datová centra (NDC) zřízená v rámci struktury Mezinárodního monitorovacího systému. Úkolem NDC v Brně je nejen zajištovat bezporuchový provoz stanice VRAC, ale také včas informovat příslušné státní autority (Státní úřad pro jadernou bezpečnost SÚJB) o významných skutečnostech souvisejících s globálním monitorováním v rámci sítě CTBTO, zejména o aktuálně uskutečněných jaderných testech. Proto jsou seismické záznamy jaderných explozí nezávisle zpracovávány také v NDC v Brně a výsledky jsou pak průběžně poskytovány pro potřeby SÚJB.

\section{Rozlišení záznamů přirozených zemětřesení a explozí}

Pro potřeby verifikace Smlouvy CTBT nestačí pouze detekovat a lokalizovat seismický jev, který by mohl odpovídat jaderné explozi, ale je nutné také zajistit spolehlivé odlišení záznamů přirozených zemětřesení od potenciálních záznamů jaderných testů. Na základě rozboru seismických dat nelze spolehlivě rozlišit jadernou a chemickou explozi, pouze lze předpokládat, že většina chemických explozí bude reprezentována jevy s magnitudem mb do hodnoty 4,5 (viz např. U. S. Congress 1988). $\mathrm{V}$ případě výjimečně silných explozí s náložemi přesahujícími 1 kt ekvivalentu TNT může být ovšem tato hodnota magnituda překročena (Khalturin et al. 1998). Proto je obtížné odlišit seismický signál slabších jaderných explozí od silných explozí chemických. Lze ovšem alespoň s dostatečnou spolehlivostí odlišit většinu přirozených jevů, které člověkem způsobenými explozemi být nemohou. 


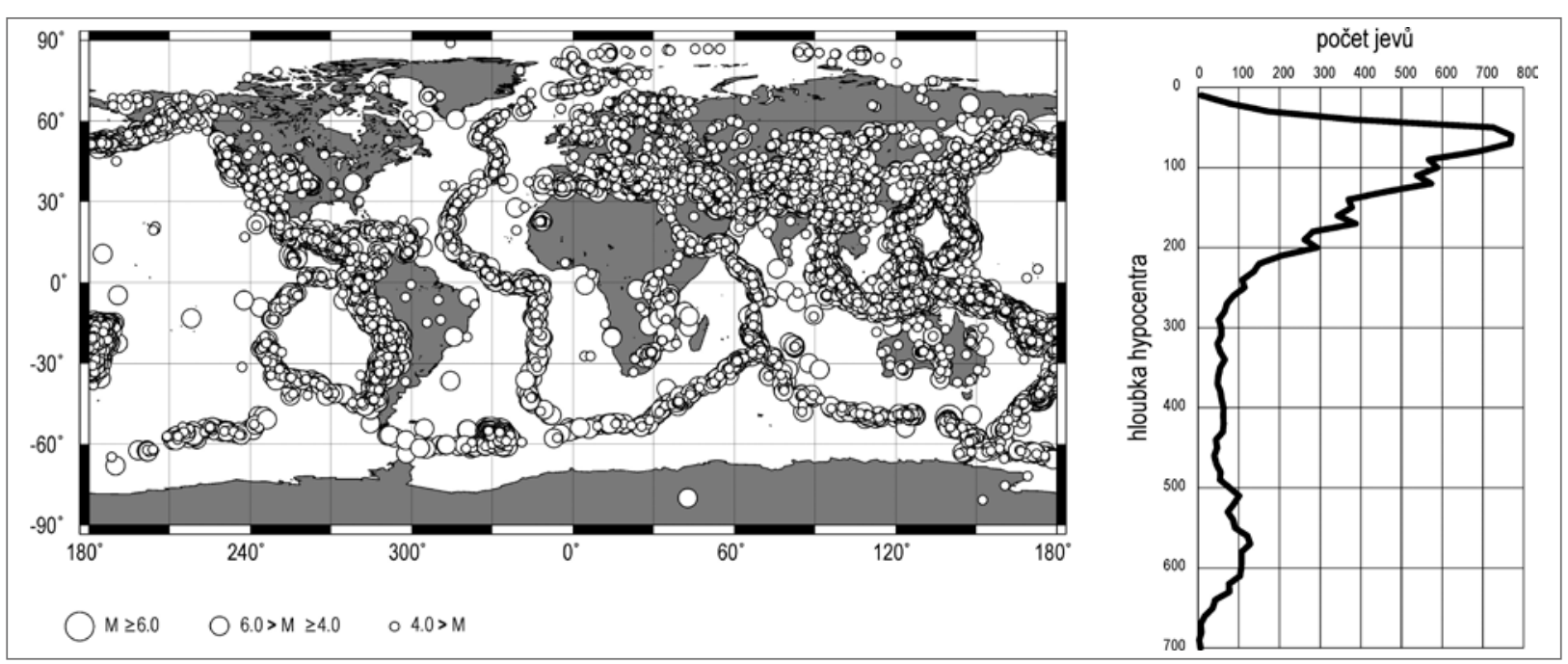

Obr. 2: Schematická mapa epicenter všech jevů lokalizovaných seismickou sítí Mezinárodního monitorovacího systému CTBTO $\mathrm{v}$ roce 2016 (vlevo) a graf rozložení hloubek hypocenter těchto jevů (vpravo).

Fig. 2: Schematic map of seismic event epicentres located by seismic network of the International Monitoring System CTBTO in year 2016 (left map) and their hypocentre depth distribution (right graph).

Seismická sít Mezinárodního monitorovacího systému CTBTO zaregistrovala a zlokalizovala v roce 2016 celkem 37090 seismických jevů (obr. 2). K lokaci 2164 $\mathrm{z}$ nich byla $\mathrm{v}$ Mezinárodním datovém centru využita stanice VRAC. Vzhledem k obrovskému množství lokalizovaných jevů je nutné, aby základní odlišení záznamů přirozených zemětřesení od záznamů explozí bylo založeno na takových postupech, které lze automatizovat. Metod využitelných k rozlišení záznamů přirozených zemětřesení a explozí je více (Bowers - Selby 2009; Pomeroy et al. 1982; U. S. Congress 1988), přednostně jsou využívány ty, které jsou jednodušší a které lze aplikovat na co největší množství registrovaných seismických jevů.

První vytřídění seismických záznamů přirozených zemětřesení je založeno již na vyhodnocení údajů lokace, tj. zeměpisných souřadnic a hloubce hypocentra. S vysokou spolehlivostí lze předpokládat, že seismické jevy s hloubkami hypocentra většími než 15 kilometrů nebudou explozemi souvisejícími s lidskou činností, a to i při započítání významné nepřesnosti v určení tohoto parametru. Hloubka hypocentra přesahující $15 \mathrm{~km}$ byla určena $\mathrm{v}$ př́padě více než 12000 seismických jevů lokalizovaných v roce 2016 Mezinárodním monitorovacím systémem CTBTO, pro více než $11900 \mathrm{z}$ těchto jevů přesáhla hloubka hypocentra hodnotu $30 \mathrm{~km}$ (obr. 2). Jenom na základě hloubky hypocentra tak je možno téměř třetinu lokalizovaných jevů označit s dostatečně vysokou spolehlivostí za přirozená zemětřesení.

Druhé rutinně využívané kritérium pro rozlišení přirozených zemětřesení a explozí je založeno na sledování poměrů amplitud povrchových a objemových vln (viz obr. 3), respektive na poměru magnituda Ms odvozeného $\mathrm{z}$ povrchových vln a magnituda mb počítaného z maximální amplitudy vln objemových. Již v 70. letech minulého století bylo zjištěno, že amplitudy povrchových vln jaderných explozí registrovaných na vzdálených stanicích jsou řádově menší ve srovnání s povrchovými vlnami mělkých zemětřesení (Basham - Horner 1973; Gupta et al. 1972; Weichert - Basham 1973). Tato skutečnost je snadno využitelná pro stanovení empirického kritéria umožňujícího definovat mělké jevy odpovídající s vysokou pravděpodobností přirozeným zemětřesením. Právě severokorejské jaderné testy ovšem ukázaly, že původní kritérium odvozené Fiskem et al. (2002) nebylo dostatečně spolehlivé (viz Bonner et al. 2008). Od roku 2012 proto bylo zavedeno v Mezinárodním datovém centru CTBTO nové kritérium založené na jednoduchém vztahu (Selby et al. 2012):

$$
\mathrm{Ms}=\mathrm{mb}-0,64
$$

Toto nové kritérium dostatečně spolehlivě reflektuje i jaderné exploze s relativně vyššími hodnotami magnituda Ms, tedy i severokorejské jaderné testy, a přitom umožňuje s dostatečnou spolehlivostí identifikovat významnou část mělkých seismických jevů jako přirozená zemětřesení (obr. 4).

Jednou z dalších jednoduchých identifikačních metod je metoda založená na výpočtu tzv. komplexity. Tato metoda vychází z faktu, že seismický záznam většiny explozí je charakteristický jednoduchým tvarem objemových vln, ve kterém dominuje pouze několik úvodních zákmitů. Oproti tomu u velkého množství přirozených zemětřesení následuje za úvodními zákmity signálu výrazná dlouhá komplexní sekvence označovaná jako „coda“ (obr. 5). Komplexita je pak veličina kvantifikující poměr energie cody vůči energii úvodní sekvence signálu (viz např. Dahy - Hassib 2009; Lay - Welc 1987; Taylor - Anderson 2009). V detailech se definice komplexity, jakožto veličiny dané konkrétní rovnicí, v různých pracích liší. Rozdíly jsou zejména v délkách časových oken zvolených pro vymezení úvodní sekvence signálu a cody. Při aplikaci této metody na severokorejské jaderné testy $\mathrm{v}$ rámci analýzy prováděné $\mathrm{v}$ NDC $\mathrm{v}$ Brně je plánováno 


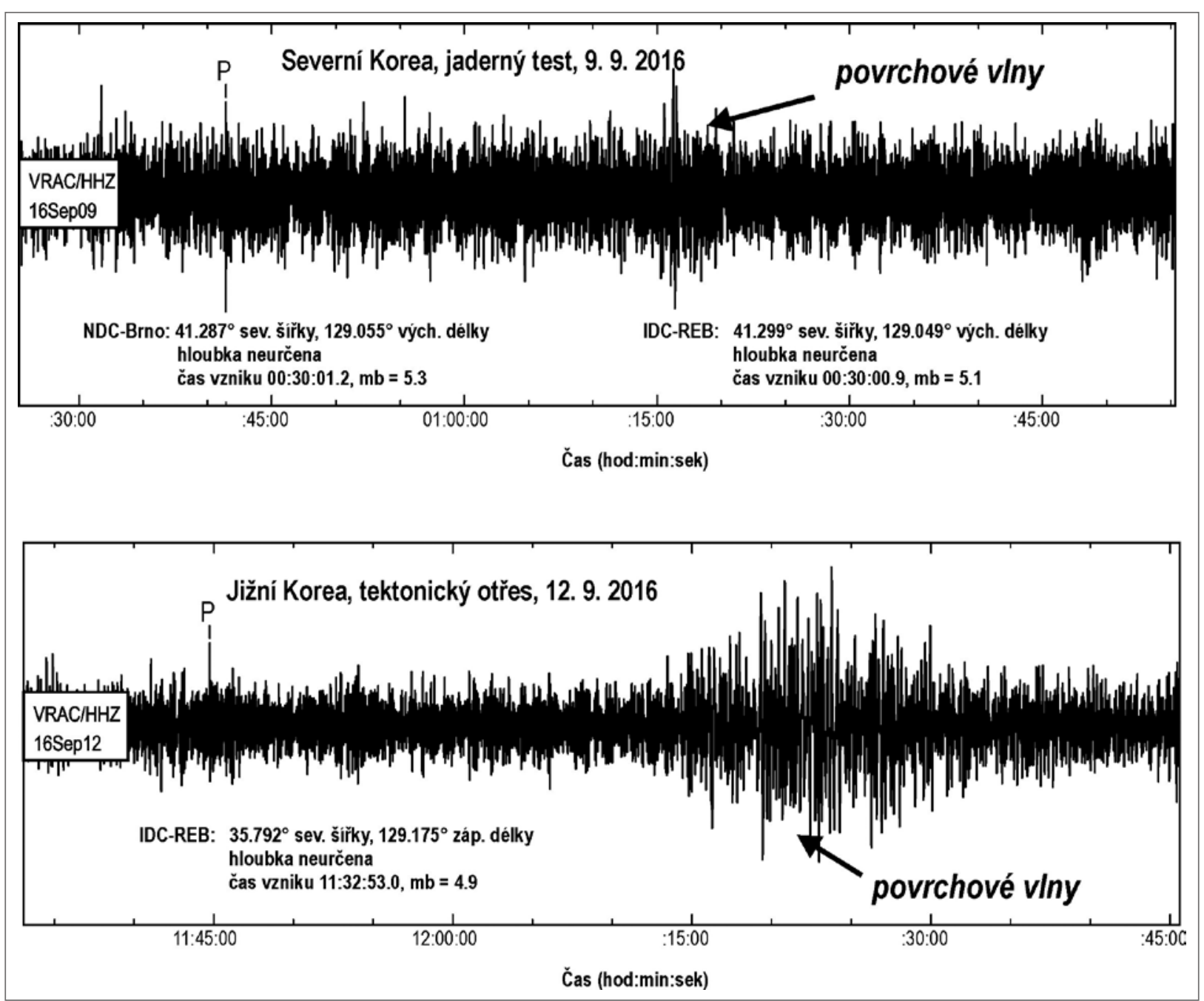

Obr. 3: Rozdíly v záznamu severokorejské jaderné exploze (nahoře) a přirozeného zemětřesení (dole) na stanici VRAC (vertikální složka, amplitudy mají nestejná měřítka). Epicentra obou jevů jsou situována ve srovnatelné epicentrální vzdálenosti od stanice VRAC.

Fig. 3: Differences between waveforms of a North Korean nuclear explosion (upper waveform) and of a natural earthquake (lower waveform) recorded by station VRAC (vertical component, amplitudes are in different scales). The epicentres of both events are situated in comparable epicentral distances from the station VRAC.

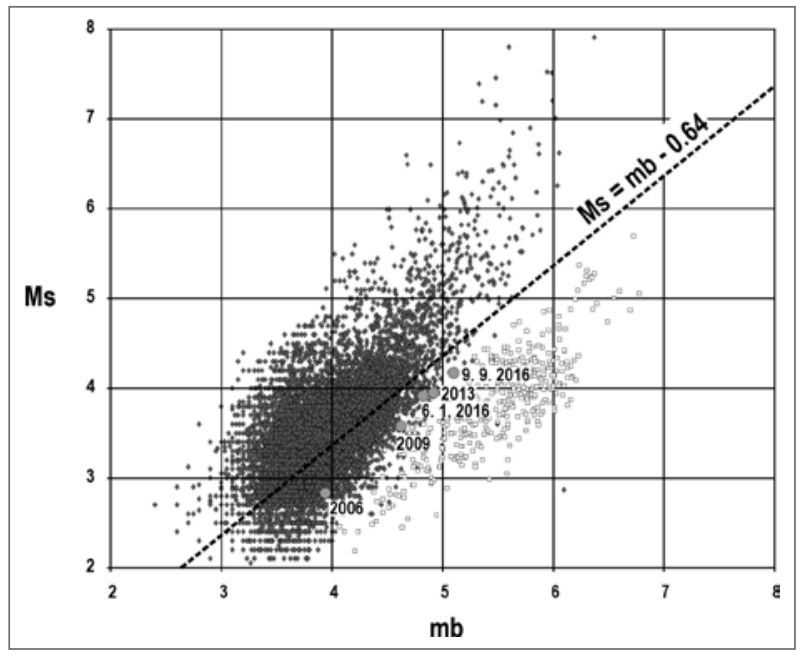

Obr. 4: Graf poměrů hodnot magnitud Ms a mb pro mělká přirozená zemětřesení (šedé kosočtverce) a jaderné exploze (bílé čtverce) s vyznačenou pozicí bodů odpovídajících severokorejským jaderným explozím (šedá kolečka). Přerušovaná čára znázorňuje kritérium pro rozlišení přirozených zemětřesení a jaderných explozí podle Selbyho et al. (2012). Údaje o hodnotách magnituda Ms a mb pro jaderné exploze jsou převzaty z práce Selby et al. (2012). Údaje pro přirozená zemětřesení jsou převzaty $z$ tzv. REB-bulletinů Mezinárodního datového centra CTBTO za rok 2016.

Fig. 4: Ms:mb plot showing ratio of Ms and mb magnitudes for shallow natural earthquakes (grey diamonds) and for nuclear explosions (white squares) with indicated points representing the North Korean nuclear explosions (grey circles). Dashed line shows the criterion for discrimination between natural earthquakes and nuclear explosions after Shelby et al. (2012). Ms and mb values of nuclear explosions are adopted after Selby et al. (2012). Ms and mb magnitudes of natural earthquakes are received from REB-bulletins of the International Data Centre CTBTO for year 2016. 


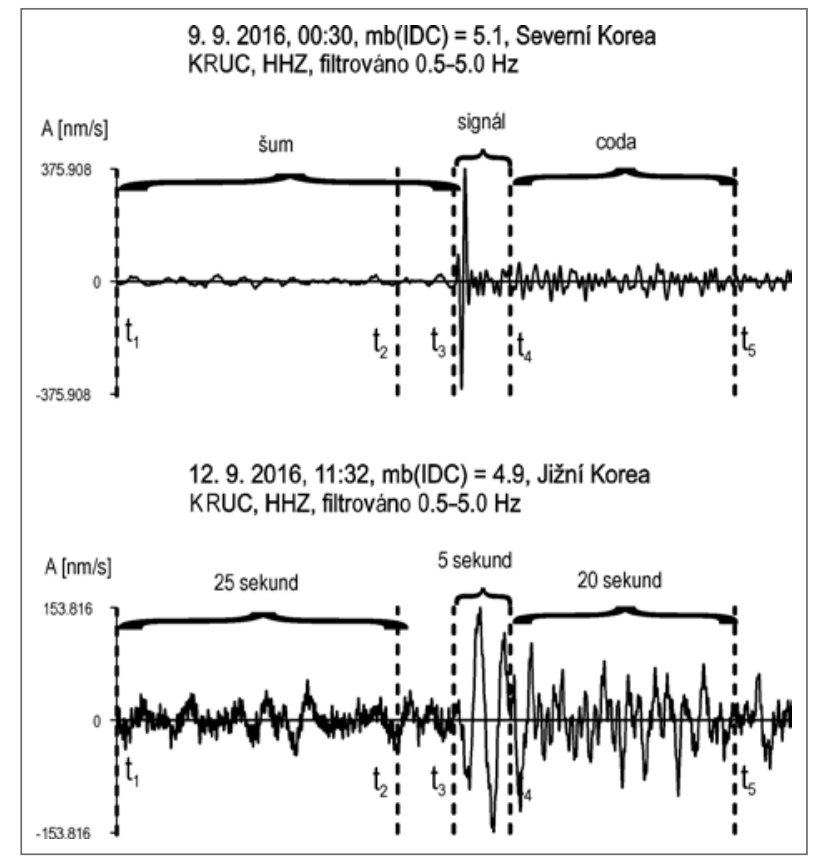

Obr. 5: Minutové úseky seismického záznamu severokorejské jaderné exploze (nahoře) a přirozeného zemětřesení (dole) na stanici KRUC (vertikální složka, filtrováno Butterwothovým filtrem v rozmezí 0,5 až $5,0 \mathrm{~Hz}$, amplitudy mají nestejná měřítka) použité pro výpočet komplexity. Na obrázku jsou vyznačeny úseky reprezentující počáteční sekvenci signálu (mezi časy $\mathrm{t}_{3}$ a $t_{4}$ ) a následující cody (mezi časy $\mathrm{t}_{4} \mathrm{at}_{5}$ ). Část záznamu před časem $t_{3}$ je reprezentována šumem, přičemž úsek mezi časy $t_{1}$ $a t_{2}$ byl využit pro charakteristiku úrovně šumu.

Fig. 5: Minute long part of seismic records of the North Korean nuclear explosion (upper waveform) and of the natural earthquake (lower waveform) recorded by station KRUC (vertical component, filtered by Butterworth filter in range 0.5 to $5.0 \mathrm{~Hz}$, amplitudes are in different scales) used for complexity study. There are marked time-windows representing initial part of the signal (between times $t_{3}$ and $t_{4}$ ) and subsequent coda (between times $t_{4}$ and $t_{5}$ ). The part before time $t_{3}$ is represented by noise, time-window between times $t_{1}$ and $t_{2}$ was used for determination of noise level.

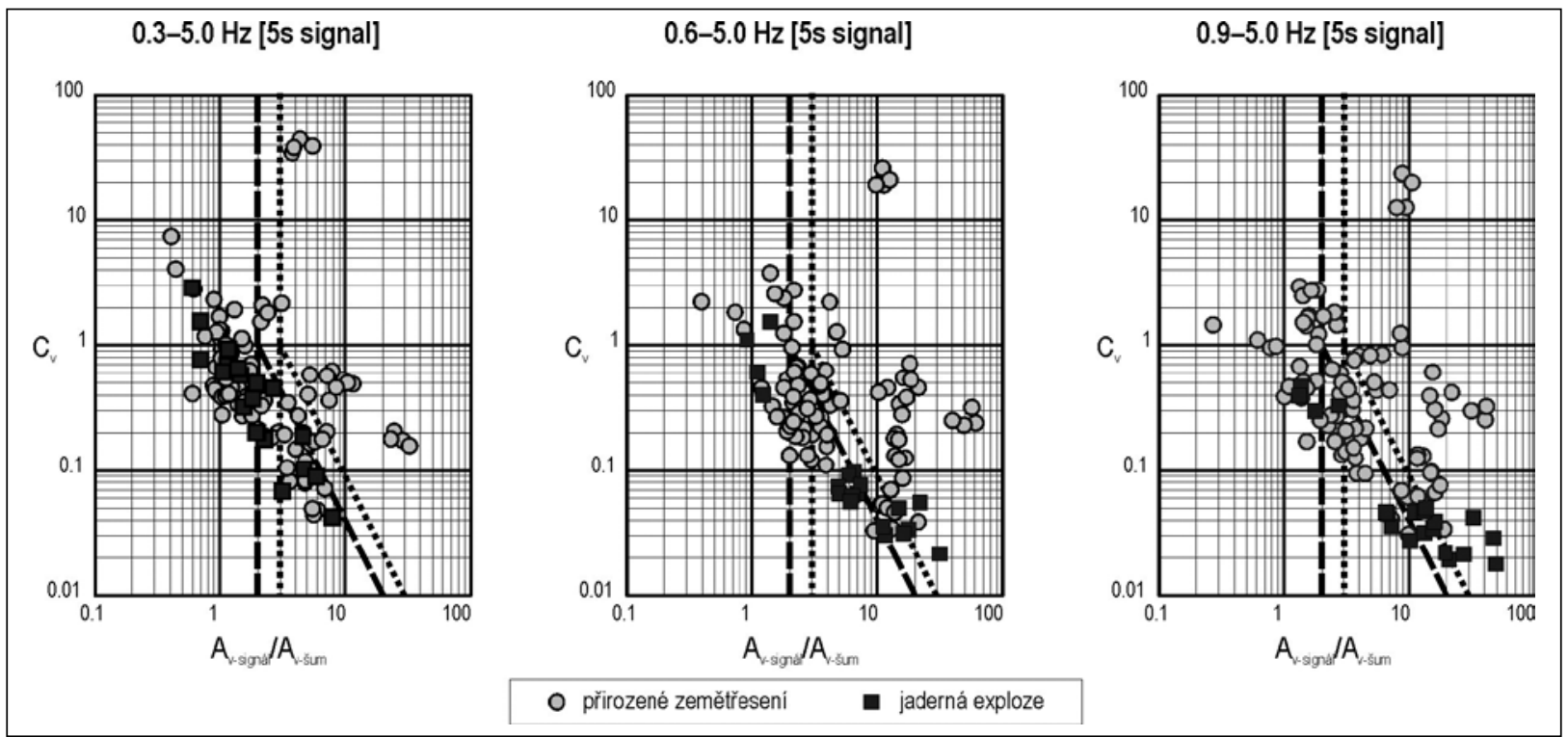

Obr. 6: Grafy komplexity $\mathrm{C}_{\mathrm{v}}$ severokorejských jaderných explozí (černé čtverce) a mělkých přirozených zemětřesení s epicentry $\mathrm{v}$ regionu jižně od KLDR (šedá kolečka, viz obr. 1) vyjádřené ve vztahu k poměru maximálních amplitud signálu $A_{v-\text { signál }}$ šumu $\mathrm{A}_{\mathrm{v}-\text { šum }}$, odvozené při různých rozmezích filtrace dat širokopásmových stanic ÚFZ (hodnota komplexity $\mathrm{C}_{\mathrm{v}}$ byla počítána zvlášt pro každou ze čtyř širokopásmových stanic ÚFZ). Přerušovaná čára znázorňuje hranici dvojnásobného poměru amplitudy signálu vůči šumu (respektive cody vůči šumu), tečkovaná čára znázorňuje hranici trojnásobného poměru amplitudy signálu vủči šumu (respektive cody vůči šumu).

Fig. 6: Complexity $\mathrm{C}_{\mathrm{v}}$ of the North Korean nuclear explosions (black squares) and shallow natural earthquakes with epicentres south of the KLDR region (grey circles, see fig. 1) plotted against ratio of signal maximum amplitude $\mathrm{A}_{\mathrm{v} \text {-signal }}$ and maximum noise amplitude $\mathrm{A}_{\mathrm{v} \text {-šum }}$, computed for various frequency ranges of filter from data of broadband seismic stations IPE (values of $\mathrm{C}_{\mathrm{v}}$ were computed individually for each broadband station IPE). Dashed line shows limit of signal amplitude in comparison to noise (respective coda amplitude in comparison of noise), dotted line shows limit of triple signal amplitude in comparison to noise (respective coda amplitude in comparison noise).

porovnat výsledky při použití různě dlouhých časových oken. Proto byl pro výpočet komplexity $\mathrm{C}_{\mathrm{v}}$ zvolen mírně upravený vztah, ve kterém jsou poměřovány energie vztažené na jednotkový časový úsek:

$$
\mathrm{C}_{\mathrm{v}}=\left(\mathrm{E}_{\mathrm{c}} / \mathrm{E}_{\mathrm{s}}\right) \times\left(\mathrm{T}_{\mathrm{s}} / \mathrm{T}_{\mathrm{c}}\right)
$$

kde $\mathrm{E}_{\mathrm{s}}$ je energie počátečního úseku signálu, $\mathrm{T}_{\mathrm{s}}$ je délka časového okna počátečního úseku signálu ( $\mathrm{tj}_{\mathrm{j}} \mathrm{t}_{4}-\mathrm{t}_{3}$, viz obr. 5), $\mathrm{E}_{\mathrm{c}}$ je energie cody a $\mathrm{T}_{\mathrm{c}}$ je délka časového okna cody (tj. $t_{5}-t_{4}$, viz obr. 5). Pro vzájemné porovnání byly hodnoty komplexity počítány v NDC v Brně jednak pro záznamy severokorejských jaderných testu a jednak pro 23 mělkých 
přirozených zemětřesení registrovaných v průběhu roku 2016 s epicentry v co nejmenší vzdálenosti od jaderné střelnice v sv. části KLDR (jižně od regionu KLDR, viz obr. 1) s hodnotami magnituda mb v rozmezí od 4,5 do 5,5. Výpočet byl proveden vždy zvlášt pro každou ze čtyř širokopásmových stanic ÚFZ, přičemž pro výpočty diskutované $\mathrm{v}$ tomto článku bylo pro počáteční úsek signálu zvoleno časové okno o délce 5 sekund a energie cody pak byla určena $\mathrm{z}$ následujícího časového úseku o délce 20 sekund.

Použitelnost vypočtené hodnoty komplexity $\mathrm{C}_{v}$ zásadně závisí na poměru užitečného signálu vůči seismickému šumu (parametry šumu byly při výpočtech prováděných $\mathrm{v}$ NDC určeny $\mathrm{z}$ úseku o délce 25 sekund mezi časy $t_{1}$ a $t_{2}$, viz obr. 5). $V$ př́padě, že je celý signál významnou měrou překrytý šumem (tj. poměr maximální amplitudy signálu vůči amplitudě šumu je menší než 3 , nebo dokonce menší než 2), nemá parametr $\mathrm{C}_{\mathrm{v}}$ de facto žádnou vypovídací hodnotu, protože ze záznamu odvozené energie ve skutečnosti neodpovídají ani energii signálu ani energii cody. Hodnota parametru $\mathrm{C}_{\mathrm{v}}$ je zkreslená také v prrípadě, kdy úvodní sekvence signálu sice dostatečně převyšuje úroveň šumu, ale stále zůstává výrazně ovlivněna šumem coda. $\mathrm{V}$ tomto př́ípadě je ale hodnota parametru $\mathrm{C}_{\mathrm{v}}$ vždy nadhodnocena, takže lze s výhodou využít alespoň faktu, že skutečná hodnota komplexity nemůže být vyšší, než hodnota odvozená z takto šumem ovlivněného záznamu.

Předběžné výsledky aplikované na záznamy severokorejských jaderných explozí ukazují, že pro účinné využití diskutované metody je důležité záznam filtrovat $\mathrm{s}$ vhodně zvoleným rozmezím frekvencí, pro které pak bude záznam dále vyhodnocován (obr. 6). Při vhodné filtraci, kdy bylo dosaženo dostatečně vysokých poměrů amplitud užitečného signálu (včetně cody) a šumu, vykazovaly záznamy severokorejských jaderných explozí (s výjimkou první exploze z roku 2006, jejíž signál byl př́lišs slabý a nebylo jej možné filtrací dostatečně extrahovat $\mathrm{z}$ šumu při žádném použitém frekvenčním rozmezí) hodnoty komplexity $\mathrm{C}_{\mathrm{v}}$ menší než 0,06 , což je zřetelně odlišovalo od výsledků zjištěných pro většinu přirozených zemětřesení. Metoda založená na výpočtu komplexity tak ukazuje u severokorejských jaderných testů na jejich genetický vztah s explozemi zřetelněji, než metoda založená na poměru magnitud Ms a mb. Právě severokorejské jaderné testy tak představují prríklad záznamů explozí, pro jejichž spolehlivou identifikaci se jeví jako vhodný postup kombinovat obě diskutované metody. Na vhodnost kombinace těchto identifikačních metod již dříve obecně upozorňovali např. Taylor a Anderson (2009).

\section{Závěr}

Zpracování záznamů severokorejských jaderných testů přineslo důležité poznatky umožňující upřesnění a doplnění postupů používaných $\mathrm{k}$ rozlišení přirozených zemětřesení a explozí. Mohou tak nejen zvýšit spolehlivost identifikačních technik aplikovaných v rámci vyhodnocení dat Mezinárodního monitorovacího systému CTBTO, ale lze je využít v rámci automatických postupů globálního seismického monitorování vůbec.

\section{Poděkování}

Př́spěvek vznikl sinanční podporou projektu MŠMT, program č. LM2015079, CzechGeo/Epos. Autor děkuje oběma recenzentưm (RNDr. Vladimíru Nehybkovi a druhému anonymnimu recenzentovi) za jejich připomínky. 


\section{Literatura}

Basham, P. W. - Horner, R. B. (1973): Seismic magnitudes of underground nuclear explosions. - Bulletin of the Seismological Society of America, 63, 105-131.

Bonner, J. - Herrmann, R. B. - Harkrider, D. - Pasyanos, M. (2008): The surface wave magbnitude of the 9 October 2006 North Korean Nuclear Explosion. - Bulletin of the Seismological Society of America, 98, 5, 2498-2506.

Bowers, D. - Selby, N. D. (2009): Forensic Seismology and the Comprehensive Nuclear-Test-Ban Treaty. - Annual Review of Earth and Planetary Sciences, 37, 209-236.

Dahy, A. S. - Hassib, H. G. (2009): Discriminating Nuclear Explosions from Earthquakes at teleseismic Distances. - European Journal of Applied Sciences, 1, 4, 47-52.

Fisk, M. D. - Jepsen, D. - Murphy, J. R. (2002): Experimental Seismic Event-screening Criteria at the Prototype International Data Center. - Pure and Applied Geophysics, 159, 865-888.

Gupta, H. K. - Sitaram, M. V. D. - Narain, H. (1972): Surface-wave and body-wave magnitudes of some sino-soviet nuclear explosions and earthquakes. - Bulletin of the Seismological Society of America, 62, 2, 509-517.

Hoffmann, W. - Kebeasy, R. - Firbas, P. (1999): Introduction to the verification regime of the Comprehensive Nuclear-Test-Ban Treaty. - Physics of the Earth and Planetary Interiors, 113, 1-4, 5-9.

Khalturin, V. I. - Rautian, T. G. - Richards, P. G. (1998): The seismic signal strength of chemical explosions. - Bulletin of the Seismological Society of America, 88, 6, 1511-1524.

Lay, T. - Welc, J. L. (1987): Analysis of near-source contributions to early P-wave coda for underground explosions. I. Waveform complexity. - Bulletin of the Seismological Society of America, 77, 3, 1017-1040.

Pomeroy, P. W. - Best, W. J. - McEvilly, T. V. (1982): Test Ban Treaty verification with regional data - a review. - Bulletin of the Seismological Society of America, 72, 6, S89-S129.

Selby, N. D. - Marshall, P. D. - Bowers, D. (2012): mb:Ms Event Screening Revisited. - Bulletin of the Seismological Society of America, 102, 1, 88-97.

Taylor, S. R. - Anderson, D. N. (2009): Rediscovering Signal Complexity as a Teleseismic Discriminant. - Pure and Applied Geophysics, 166, 325-337.

Weichert, D. H. - Basham, P. W. (1973): Deterrence and false alarms in seismic dicsrimination. Bulletin of the Seismological Society of America, 63, 1119-1132.

U.S. Congress, Office of Technology Assessment (1988): Seismic Verification of Nuclear Testing Treaties. - OTA-ISC-361, U.S. Government Printing Office. Washington D.C. 